\title{
Qualitative Phytochemical Screening and GCMS-Derived Fatty Acid Composition of Ethanolic Seed Extract of Cola lepidota K. Schum
}

\author{
O.G. Chukwuemeka ${ }^{1 *}$, P.N. Okafor ${ }^{1}$, P. Nwankpa ${ }^{2}$, C.C. Etteh ${ }^{2}$, C.N. Ekweogu ${ }^{2}$, \\ P.C. Ugwuezumba ${ }^{3}$, F.C. Emengaha ${ }^{2}$, J.N. Egwurugwu ${ }^{3}$ and D.I. Izunwanne ${ }^{3}$ \\ ${ }^{1}$ Department of Biochemistry, Michael Okpara University of Agriculture, Umudike, \\ Abia State, Nigeria \\ ${ }^{2}$ Department of Biochemistry, Imo State University, Owerri, Imo State, Nigeria \\ ${ }^{3}$ Department of Medical Physiology, Imo State University, Owerri, Imo State, Nigeria \\ *Corresponding author
}

\begin{abstract}
A B S T R A C T

\begin{tabular}{|l|}
\hline K e y w o r d s \\
$\begin{array}{l}\text { Cola lepidota, Retention } \\
\text { time, Peak area, } \\
\text { Phytochemicals, Fatty } \\
\text { acids, Ethanolic, Seed } \\
\text { extract }\end{array}$ \\
\hline Article Info \\
\hline $\begin{array}{l}\text { Accepted: } \\
\text { 04 November } 2018 \\
\text { Available Online: } \\
\text { 10 December } 2018\end{array}$ \\
\hline
\end{tabular}

The qualitative phytochemical screening of the ethanolic seed extract of Cola lepidota revealed the presence of important phytochemicals. The GCMS fatty acid chromatogram showed that the extract contained fourteen fatty acid compounds and out of the fourteen compounds, five were more prominent with the peaks corresponding to the retention time range of $18.008-21.020$. The peak at 19.779 retention time is the largest and has a peak area of $43.23 \%$. This largest peak is identified as linoleic acid methyl ester while the second largest peak at 19.336 retention time with peak area $14.68 \%$ is due to the presence of 1,5-cyclododecadiene. The third largest peak at 21.020 retention time with the peak area of $11.85 \%$ is Bis(2-ethylhexyl) phthalate while the fourth largest peak at 20.015 retention time with the peak area $8.98 \%$ represents octadecanoic acid methyl ester. The fifth largest peak at the retention time of 18.008 and peak area of $7.03 \%$ represents methylhexadecanoic acid. The importance of these phytochemicals is discussed.
\end{abstract}

Introduction

Medicinal plants are so called because they contain various biologically active components which are largely products of plant secondary metabolism usually referred as phytochemicals or natural products. These bioactive compounds can be used to treat chronic as well as infectious diseases (Duraipandiyan et al., 2006).

Phytochemicals may be located richly in the root, stem, bark, leaf, fruit, seed, seed coat, 
from medicinal plants called natural products are still major sources of innovative therapeutic agents for various conditions, including infectious diseases.

The actual date or period when and the first place where medicinal plant usage for treating ailments commenced is largely unknown. However, many reports have shown that medicinal plants usage in treating ailments is as old as man. Ever since antiquity, people looked for drugs in nature to cure their diseases. According to Stojanoski (1999), the commencing of the medicinal plants' use was instinctive, as is the case with animals. That is to say that there was paucity of information relating either the reasons for the illnesses or which plant and how it could be utilized as a cure. Thus, everything was based on experience (Biljana, 2012).

Biljana (2012) also reported that the connection between man and his search for drugs in nature dates from the far past, of which there is ample evidence from various sources: written documents, preserved monuments, and even original plant medicines.

Conventional medicine has acknowledged the efficacies of medicinal plants leading to their inclusion in modern medicine. Many drugs today are from plant origin and many of such drugs have been known since antiquity. In 2001, researchers identified 122 compounds used in modern medicine which were derived from traditional plant sources, $80 \%$ of these have had a traditional use identical or related to the current use of the active elements of the plant (Fabricant and Farnsworth, 2001).

Some of the pharmaceuticals currently available to physicians are derived from plants that have a long history of use as herbal remedies, including aspirin, digoxin, quinine, and opium (Swain, 1968).
Awareness of medicinal plants usage is a result of the many years of struggles against illnesses due to which man learned to pursue drugs in barks, seeds, fruit bodies, and other parts of plants (Biljana, 2012). As mentioned earlier, there are many ample written evidence pertaining medicinal plants' usage in drug preparation, the study of herbs according to Sumner (2000) dates back over 5,000 years to the Sumerians who created clay tablets with lists of hundreds of medicinal plants (such as myrrh and opium).

Cola lepidota is a member of the family of Sterculiaceae and belongs to a group called drupes (Pamplona-Roger, 2008). The pod of Cola lepidota is yellowish and roundish and is also called Yellow Monkey Kola, while the white variety which is Cola parchycarpahas more cylindrical shape and is also called White Monkey Kola. Cola lepidota is cultivated throughout the tropical regions of the world. It is commonly found in Southern Nigeria between the months of June to November (Ogbu et al., 2007). Cola lepidota fruits are highly nutritious and medicinal (Pamplona-Roger, 2008) and Cola lepidota (having yellow pod), Cola parchycarpa (having white pod) and Cola lateritia (having red pod) all belong to the family of monkey kola (Okudu et al., 2015).

Cola lepidota is a selected specie for this study because of its traditional use in some parts of Abia State as a weight reducer and research findings have shown that it contains significantly higher phytochemical constituents than other species and it is more widely distributed (Oghenerebo and Falodun, 2013; Okudu et al., 2015; Essien et al., 2015). Okudu et al., (2015) reported that Cola lepidota juice contains significantly higher phytochemical constituents than Cola parchycarpa. Also, Okudu et al., (2015) were able to investigate the phytochemical constituents of the membranes and seeds of 
Cola lepidota and revealed that B-vitamins, particularly riboflavin and niacin were found in significant amount in Cola lepidota membrane and both $C$. lepidota and $C$. parchycarpa had substantial amounts of phytochemicals (particularly alkaloids, phenols, flavonoids and saponins. Essien et al., (2015) detected from their phytochemical screening, alkaloids, saponins, terpenoids, carbohydrates, and flavonoids in the seeds and fruit pulp extracts of C. lepidota $K$. Schum and C. rostrata.

The Cola lepidotafruit was identified at Forestry Department, Michael Okpara University of Agriculture Umudike, Abia State, Nigeria.

Fig. A: Cola lepidota fruit with its scaly brownish exocarp

The figure $\mathrm{A}$ is the mature, intact Cola lepidota fruit. It shows the scaly exocarp that is usually hard but can be easily cut open with a knife. The fruit does not have a definite shape. Its shape comes from the shape and size of the seed inside it. The exocarp is usually brownish in colour and covered with tiny hairs. This portion of the exocarp must be removed to get to the edible yellowish mesocarp.

Fig. B: Cola lepidota fruit showing the edible yellow mesocarp

The figure B shows two slightly torn scaly exocarps, revealing the edible yellow pulps as well as two yellow pulps completely devoid of the scaly exocarp. It is these yellow pulps that are often relished.

\section{Fig. C: Cola lepidota seeds}

The figure $\mathrm{C}$ shows three Cola lepidota seeds which are obliquely ovoid with two flattered surfaces and are usually rough with either reddish-brown or greenish colour. The seeds contain hairy spines within the interior of the opposing faces. These hairy spines could be the major reason why earlier people preferred consuming its closer specie, Cola nitida.

The high burden of cardiovascular disease (CVD) in the developing countries is attributable to the increasing incidence of atherosclerotic diseases, perhaps due to urbanization and higher risk factor levels (such as obesity, diabetes, dyslipidemia, hypertension, etc) (Murray and Lopez, 1996).

With urbanization, changing lifestyles, diminished assess/availability of fresh vegetables as well as increased consumption of processed foods, the number of people with obesity tends to increase. Therefore, a critical management of traditional medicinal plant resources has become a matter of urgency (Zschocke et al., 2000).

Studies have shown that Cola lepidota seeds contain significant phytochemicals that could be of therapeutic importance but not much is known about the fatty acid compositions hence the need for the GCMS fatty acid analysis.

The aim of this study is to reveal the fatty acid components of the ethanolic seed extract of Cola lepidota using GCMS method as well as qualitatively revealing some of the phytochemicals present in the extract.

\section{Materials and Methods}

\section{Collection of plant materials}

Cola lepidota K. Schum fruits were purchased from a local market in Aba, Abia State, Nigeria and were identified in the Forestry Department of Michael Okpara University of Agriculture, Umudike by Mr. Ibe Ndukwe and 
the seed specimen stored in the Department's herbarium.

Preparation of plant seed extract for phytochemical screening

The seeds were removed from their pods and sun-dried and ground to fine powder and stored in an air-tight container till when needed for the experiment.

Hot continuous extraction with soxhlet extractor was used to obtain the organic compounds from the dry ground seed powder and the solvent used was pure ethanol (99\%) in order to obtain polar lipids (usually, the membrane bound lipids such as the phospholipids and glycolipids). The temperature was maintained at $40^{\circ} \mathrm{C}$ (so as not to degrade certain compounds in the seed) for 8 hours in order to obtain the complete extraction of the sample.

The procedure involved weighing $200 \mathrm{~g}$ of the powdered sample into a cellulose thimble in the soxhlet extractor containing about $600 \mathrm{ml}$ of the pure ethanol. The sample was refluxed for 8 hours at $40^{\circ} \mathrm{C}$ using a condenser (with running cold water) attached to the top of the soxhlet. This condenser droped the temperature quickly, enabling the condensation of the solvent on the sides of the glass to drop back into the cellulose thimble. The solvent was allowed to cool to room temperature and filtered with Whatman No. 1 filter paper (Whatman International Ltd, England) to remove any particulate matter. The filtrate was concentrated using a rotary evaporator (RE-52A, Union Laboratories, England) and kept in a refrigerator (Thermocool, England) at about $4{ }^{\circ} \mathrm{C}$ prior to phytochemical screening by means of Gas Chromatography-Mass Spectrometry (GCMS) (GCMS (QP2010 PLUS), Shimadzu, Japan) (for structural determination of the fatty acids in the extract).
Qualitative phytochemical analyses of the ethanolic seed extract of Cola lepidota

The phytochemical screening of the extract was done to detect the presence or absence of secondary metabolites (phytochemicals) using the standard methods described below.

Test for reducing sugars (Trease and Evans, 1996)

A known mass of $1 \mathrm{~g}$ of sample and $10 \mathrm{ml}$ of distilled water were boiled for $10 \mathrm{mins}$ and then $200 \mu \mathrm{L}$ of Fehling's solutions (A and B) were added to $1 \mathrm{ml}$ of filtrate and boiled. Brick red precipitate was indicative of the presence of reducing sugar.

\section{Test for flavonoids (Trease and Evans, 1996)}

\section{Lead acetate test}

To $2.0 \mathrm{ml}$ portion of the extract was added a few drops of $10 \%$ lead acetate solution. A cream or light yellow colouration showed the presence of flavonoids.

\section{Aluminium chloride test}

To $2.0 \mathrm{ml}$ portion of the extract was added a few drops of $1 \%$ aluminium chloride solution and observed for light yellow colouration. A yellow precipitate indicated the presence of flavonoids.

\section{Test for tannins (Trease and Evans, 1996)}

\section{Ferric chloride test}

To $1.0 \mathrm{ml}$ portion of the extract, $4.0 \mathrm{ml}$ of distilled water was added and a few drops of $10 \%$ ferric chloride solution were also added. The solution was then observed for blue or green precipitate colouration indicating the presence of tannins. 
Test for saponins (Trease and Evans, 1996)

\section{Emulsion test}

To $2.0 \mathrm{ml}$ portion of the extract $4 \mathrm{ml}$ of distilled water was added and shaken vigorously for 2 min after which a few drops of olive oil were added. Formation of an emulsion showed the presence of saponins.

Test for resins (Sofowora, 1993)

\section{Acetone-water test}

After boiling $1 \mathrm{~g}$ of sample and $10 \mathrm{ml}$ of $96 \%$ ethanol for 5 mins, $3 \mathrm{ml}$ acetone and $3 \mathrm{ml}$ conc. $\mathrm{HCl}$ acid were added and further boiled for 3 mins. The presence of a white precipitate showed the presence of resins.

\section{Test for phenol}

\section{Ferric chloride test}

To $2 \mathrm{ml}$ of ethanol, $0.05 \mathrm{~g}$ of portion of the extract added followed by few drops of aqueous solution of ferric chloride. A formation of reddish colour precipitate indicates the presence of phenols.

Test for carbohydrates (Sofowora, 1993)

\section{Molisch test}

Ten millilitres $(10 \mathrm{ml})$ of distilled water and 1 $\mathrm{g}$ extract were boiled for 5 mins and filtered.

Then $1 \mathrm{ml}$ of the filtrate, $100 \mu \mathrm{l}$ Molisch reagent solution and $1 \mathrm{ml}$ conc. $\mathrm{H}_{2} \mathrm{SO}_{4}$ were added and observed. Browning observed at the interface revealed the presence of carbohydrates.

\section{Test for oil (Sofowora, 1993)}

A part of the extract was smeared on a filtered paper to observe for transluscence on the paper.

\section{Test for proteins}

\section{Biuret test}

The extract were treated with $1 \mathrm{ml}$ of $10 \%$ sodium hydroxide solution and heated. To this, a drop of $0.7 \%$ copper sulphate solution $\left(\mathrm{CuSO}_{4}(\mathrm{aq})\right.$ was added. Formation of purplish violet colour indicates the presence of proteins.

\section{Test for steroid (Trease and Evans, 1996)}

Five (5) $\mathrm{ml}$ of aqueous extract was added to 2 $\mathrm{ml}$ chloroform and $3 \mathrm{ml}$ of concentrated $\mathrm{H}_{2} \mathrm{SO}_{4}$ were added cautiously for a reddish brown intermittent layer, which confirms a positive result.

Test for alkaloid (Trease and Evans, 1996)

A few drops of the following reagents were added to each of $2.0 \mathrm{ml}$ of the extract, and observed for colour change:

\section{Dragendorf reagent}

A red to orange precipitate indicated the presence of alkaloids.

\section{Wagner's reagent}

A reddish or deep-brown precipitate indicated the presence of alkaloids

Test for glycosides (Trease and Evans, 1996)

A known mass of $1 \mathrm{~g}$ of sample and $10 \mathrm{ml}$ of water were boiled for 5 minutes. Then $400 \mu \mathrm{l}$ of equal (v/v) mixture of Fehlings solutions A and $\mathrm{B}$ was added to $2 \mathrm{ml}$ of filtrate to which 2 $\mathrm{ml}$ of dilute ammonia solution $\left(\mathrm{NH}_{3(\mathrm{aq})}\right)$ was added and boiled for 5 - 10 mins. The filterate changed to a brick red precipitate, indicating the presence of glycosides. 
Test for terpenoids (Salkowski Test) (Trease and Evans, 1996)

Five $\mathrm{ml}$ of extract was mixed in $2 \mathrm{ml}$ of chlorofoam, and $3 \mathrm{ml}$ of concentrated $\mathrm{H}_{2} \mathrm{SO}_{4}$ was carefully added to form a layer. A reddish brown colouration of the interface was formed indicating a positive result for the presence of terpenoid compounds.

Analysis of fatty acid composition of ethanolic seed extract using gas chromatography-mass spectrometry (GCMS)

The ethanol seed extract of Cola lepidota was subjected to GC-MS analysis on the instrument GCMS-QP2010 PLUS SHIMADZU, JAPAN. The oven temperature was programmed at $60^{\circ} \mathrm{C}$ for $0 \mathrm{~min}$, and was gradually increased to $140^{\circ} \mathrm{C}$ at $4.0 \mathrm{~min}$ and then ending with $250^{\circ} \mathrm{C}$ at $6 \mathrm{~min}$. A sample volume of $8.0 \mu \mathrm{l}$ was injected for analysis. Helium gas $99.995 \%$ of purity was used as a carrier gas as well as an eluent. The flow rate of helium gas was set to $1.61 \mathrm{ml} / \mathrm{min}$. The sample injector temperature was maintained at $200{ }^{\circ} \mathrm{C}$ and the split ratio was 1.0 throughout the experiment periods.

The ionization mass spectroscopic analysis was done with $70 \mathrm{eV}$. The mass spectra were recorded for the mass range $35-800 \mathrm{~m} / \mathrm{z}$ for about $25 \mathrm{~min}$. Identification of components was based on comparison of their mass spectra. As the compounds separated on elution through the column, they were detected in electronic signals. As individual compounds eluted from the Gas chromatographic column, they entered the electron ionization detector where they were bombarded with a stream of electrons causing them to break apart into fragments. The fragments were actually charged ions with a certain mass.
The $\mathrm{m} / \mathrm{z}$ ratio obtained was calibrated from the graph obtained which was called the mass spectrum graph which is the fingerprint of the molecule. Interpretation of mass spectrum GC-MS was conducted using the database of National Institute of Standard and technology (NIST) having more than 62,000 patterns. The spectrum of the unknown component was compared with the spectrum of the known components stored in the NIST Library 2008 WILEY8, FAME. The Name, Molecular weight and structure of the components of the test materials were ascertained.

\section{Results and Discussion}

Table 1 reveals some of the phytochemicals contained in the ethanolic seed extract of Cola lepidota. The concentrations of the phytochemicals were not obtained. The qualitative method was to detect the presence $(+)$ or absence (-) of the above phytochemicals.

\section{GC-MS analysis of ethanolic seed extract of Cola lepidota}

GC-MS analysis of the ethanol seed extract of Cola lepidota was carried out. The Chromatogram of Cola lepidota seed extract is shown in figure 1. A total of fourteen (14) compounds were identified. The Chromatogram shows 5 prominent peaks in the retention time range $18.008-21.020$. The peak at 19.779 retention time is the largest peak and has a peak area of $43.23 \%$. This largest peak is due to the presence of linoleic acid methyl ester. The Second less prominent peak at 19.336 retention time with the peak area $14.68 \%$ is due to the presence of $1,5-$ Cyclododecadiene. The third less significant peak at 21.020 retention time with the peak area $11.85 \%$ is Bis (2-ethylhexyl) phthalate.

The Fourth less prominent peak at 20.015 retention time with the peak area $8.98 \%$ 
denotes octadecanoic acid methyl ester while the last prominent peak at 18.008 retention time with peak area $7.03 \%$ is hexadecanoic acid methyl ester. The other less prominent peaks at other retention times are given in appendix. The table 2 shows the fatty acids of the seed extract obtained by GCMS analysis. The table 2 shows all the fatty acids as obtained.

The qualitative phytochemical screening of the ethanolic seed extract of $C$. lepidota reveals the presence of phenols, flavonoids, steroids, saponins, tannins, alkaloids, carbohydrates, phenols, fats and oils, and terpenoids and this result is supported by the works of Okudu et al., (2015) and Essien et al., (2015) which reported the presence of such phytochemicals in $C$. lepidota seeds.

Therefore, the seed of C. lepidota is a good repository for a host of important phytochemicals that are capable of treating certain disease conditions. Some of these compounds have antioxidant activities for instance; Oktay et al., (2003) reported that there is a strong positive relationship existing between total phenolic contents and antioxidant activity which appears to be the trend in many plant species.

Rice-Evans et al., (1997) reported that under experimental conditions, the antioxidative potentials of plant phenolics are always linked to their electron donation, reducing power, and metal-chelating ability.

Sakihama et al., (2002) and Michalak (2006) revealed that flavonoids and other phenylpropanoids act as hydrogen peroxide scavengers as they are oxidized by peroxidase. Apart from possessing antioxidant quality, studies have also revealed flavonoids as exhibiting other multiple biological effects such as antiviral (Weber et al., 2003), antibacterial (Alvesalo et al., 2006), antiinflammatory (Subarnas and Wagner, 2000 and Wildlansky et al., 2005), vasodilatory (Calderone et al., 2004), anticancer (Formica and Regelson, 1995), and antiischemic (Rump et al., 1995; Duthie et al., 2000, and Mladenka et al., 2010).

They are also able to inhibit lipid peroxidation and platelet aggregation and improve increased capillary permeability and fragility (Valensi et al., 1996; Hubbard et al., 2004; Cirico and Omaye, 2006).Evidence has shown that alkaloids have antidiabetic and antioxidant properties (Khalijah et al., 2013).

Evidence shows that phenolics and saponins have high antioxidative potentials and could be applied in nutraceuticals, functional foods as well as acting as natural food preservatives (Kim et al., 2004).

Studies have revealed that tannins also possess strong antioxidant properties (Hagerman et al., 2001; Ken et al., 2002; Ryszard, 2007; Koleckar et al., 2008; Karamac, 2009 and Muhammad et al., 2013). Natural pancreatic lipase (PL) inhibitors such as saponins, polyphenols, terpenes, and microbial byproducts have been described as unexplored potentials in the management of obesity and new drug discovery (Najla et al., 2012).

Flavonoids have been to reduce lipid profile by inhibiting hepatic HMG-CoA reductase (Jung et al., 2006).

Enechi et al., (2014) reported that C. lepidota seed extract may also inhibit cholesterol absorption from the intestine due to the formation of complexes with compounds such as glycosides and saponins while Mijake et al., (1998) reported that flavonoids decrease the total cholesterol and triacylglycerols of rats. 
Table.1 Qualitative phytochemical analysis of ethanolic seed extract of Cola lepidota

\begin{tabular}{|c|c|c|c|}
\hline Compounds & Method/Test Type & $\begin{array}{l}\text { Detected (+) or } \\
\text { Not detected (-) }\end{array}$ & Indicator \\
\hline Flavonoids & Aluminium chloride test & + & Yellow precipitate \\
\hline Cardiac glycosides & Fehling's solution (A and B) test & - & Brick red precipitate \\
\hline Steroids & Trease and Evans (1996) Method & + & Reddish-Brown colouration \\
\hline Saponins & Froth Method & + & Formation of emulsion \\
\hline Tannins & Ferric chloride test & + & Brownish-green precipitate \\
\hline Alkaloids & Wagner's reagent test & + & $\begin{array}{l}\text { Reddish or Deep brown } \\
\text { precipitate }\end{array}$ \\
\hline Carbohydrates & Molisch test & + & $\begin{array}{l}\text { Formation of Brown } \\
\text { Colouration }\end{array}$ \\
\hline Phenols & Ferric chloride test & + & Muddy brown precipitate \\
\hline Reducing sugars & Fehling's solution (A and $\mathrm{B}$ ) test & - & Brick red precipitate \\
\hline Fats and Oil & Transluscent method & + & $\begin{array}{l}\text { Formation of transluscence on } \\
\text { filter paper }\end{array}$ \\
\hline Protein & Biuret test & - & Purplish colouration \\
\hline Terpenoids & Salkowski test & + & $\begin{array}{l}\text { A reddish-brown colouration } \\
\text { at the interface }\end{array}$ \\
\hline Resins & Acetone-water test & - & $\begin{array}{l}\text { Formation of white } \\
\text { precipitate }\end{array}$ \\
\hline
\end{tabular}

Table.2 Identified fatty acid compounds in ethanol seed extract of Cola lepidota with their Retention Times (RT), Peak Areas, Molecular Weights (MW) and molecular formulae

\begin{tabular}{|l|l|l|l|l|l|}
\hline Peak & RT & Name of compound & $\begin{array}{l}\text { Molecular } \\
\text { formula }\end{array}$ & MW & $\begin{array}{l}\text { Peak area } \\
\%\end{array}$ \\
\hline 1 & 5.378 & 3,7-Dimethylnonane & $\mathrm{C}_{11} \mathrm{H}_{24}$ & 156 & 0.53 \\
\hline $\mathbf{2}$ & 14.419 & Alpha-(tert-butylsulfinyl)toluene & $\mathrm{C}_{11} \mathrm{H}_{16} \mathrm{OS}$ & 196 & 0.24 \\
\hline $\mathbf{3}$ & 14.572 & p-Hydroxyphenyl benzyl ether & $\mathrm{C}_{13} \mathrm{H}_{12} \mathrm{O}_{2}$ & 200 & 0.12 \\
\hline $\mathbf{4}$ & 16.400 & 4-Isopropyl-1,7-dimethylcyclodecane & $\mathrm{C}_{15} \mathrm{H}_{30}$ & 210 & 0.66 \\
\hline $\mathbf{5}$ & 17.606 & 1,2-Benzenedicarboxylic acid & $\mathrm{C}_{16} \mathrm{H}_{22} \mathrm{O}_{4}$ & 278 & 0.63 \\
\hline $\mathbf{6}$ & 18.008 & Methylhexadecanoate & $\mathrm{C}_{17} \mathrm{H}_{34} \mathrm{O}_{2}$ & 270 & 7.03 \\
\hline $\mathbf{8}$ & 19.366 & 1,5-Cyclododecadiene & $\mathrm{C}_{12} \mathrm{H}_{20}$ & 164 & 14.68 \\
\hline $\mathbf{9}$ & 19.779 & Linoleic acid methyl ester & $\mathrm{C}_{19} \mathrm{H}_{34} \mathrm{O}_{2}$ & 294 & 43.23 \\
\hline $\mathbf{1 0}$ & 20.015 & Octadecanoic acid methyl ester & $\mathrm{C}_{19} \mathrm{H}_{38} \mathrm{O}_{2}$ & 298 & 8.98 \\
\hline $\mathbf{1 1}$ & 20.648 & 9Z)-9,17-Octadecadienal & $\mathrm{C}_{18} \mathrm{H}_{32} \mathrm{O}$ & 264 & 4.68 \\
\hline $\mathbf{1 2}$ & 20.812 & Farnesyl alcohol & $\mathrm{C}_{15} \mathrm{H}_{26} \mathrm{O}$ & 222 & 4.01 \\
\hline $\mathbf{1 3}$ & 21.020 & Bis(2-ethylhexyl) phthalate & $\mathrm{C}_{24} \mathrm{H}_{38} \mathrm{O}_{4}$ & 390 & 11.85 \\
\hline 14 & 21.809 & Dimethylhexylsilyl chloride & $\mathrm{C}_{8} \mathrm{H}_{19} \mathrm{ClSi}$ & 178 & 1.80 \\
\hline
\end{tabular}

Table 2 above shows the fourteen (14) fatty acid compounds obtained from the ethanolic seed extract of Cola lepidota using GCMS method. Out of this fourteen (14) compounds, five (5) were more prominent as indicated by their percentage $(\%)$ peak areas. These prominent compounds are methylhexadecanoate, 1, 5-cyclododecadiene, linoleic acid methyl ester, octadecanoic acid methyl ester, and bis (2-ethylhexyl) phthalate. 
Fig.1 Chromatogram of ethanolic seed extract of Cola lepidota

\section{NARICT, ZARIA \\ INDEVLUIV KLUS SHMMADZUJAPAN GCMS ANALYSIS GODFREY OBVIOUS}

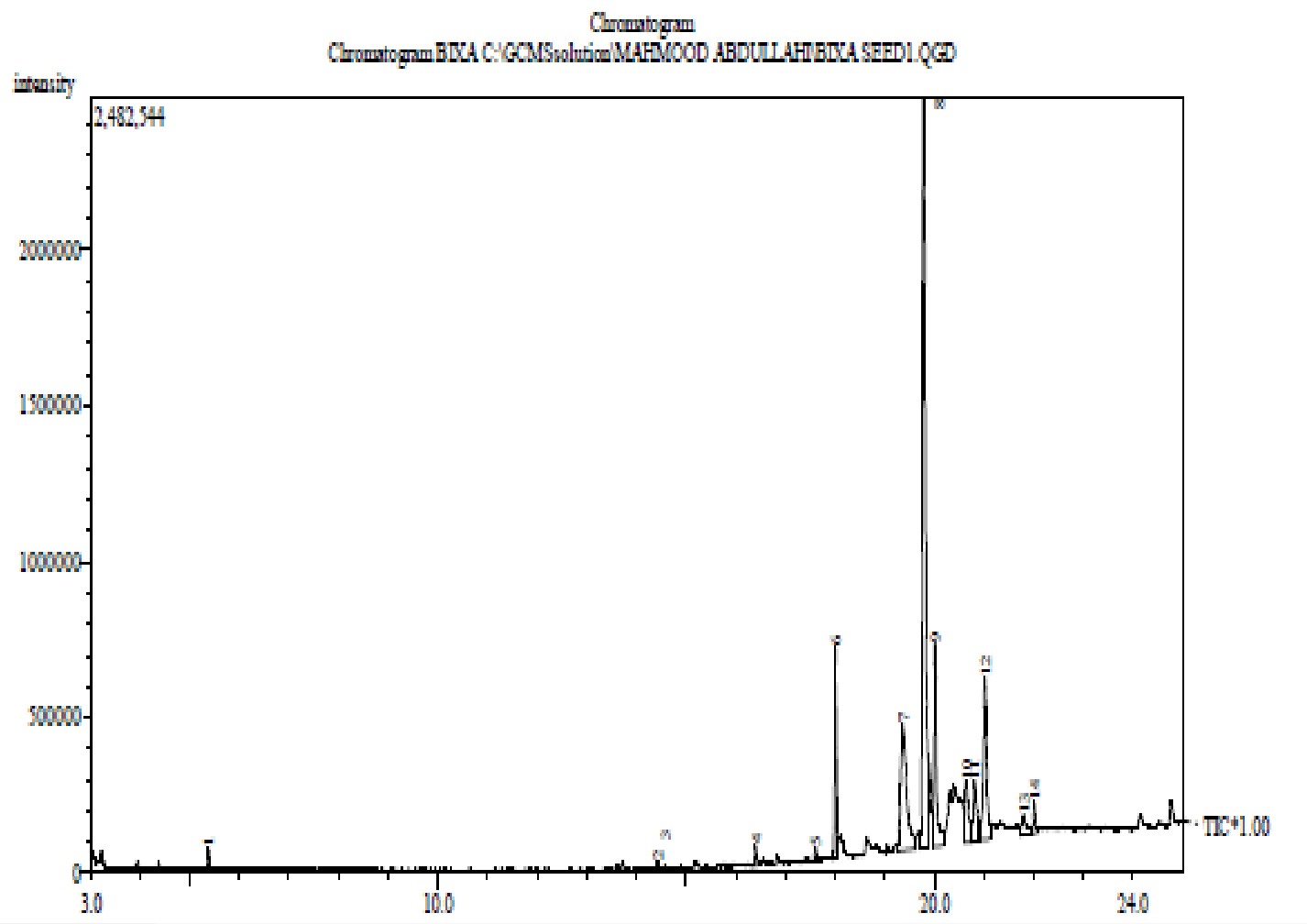

Fig.A and B Cola lepidota fruits and seeds

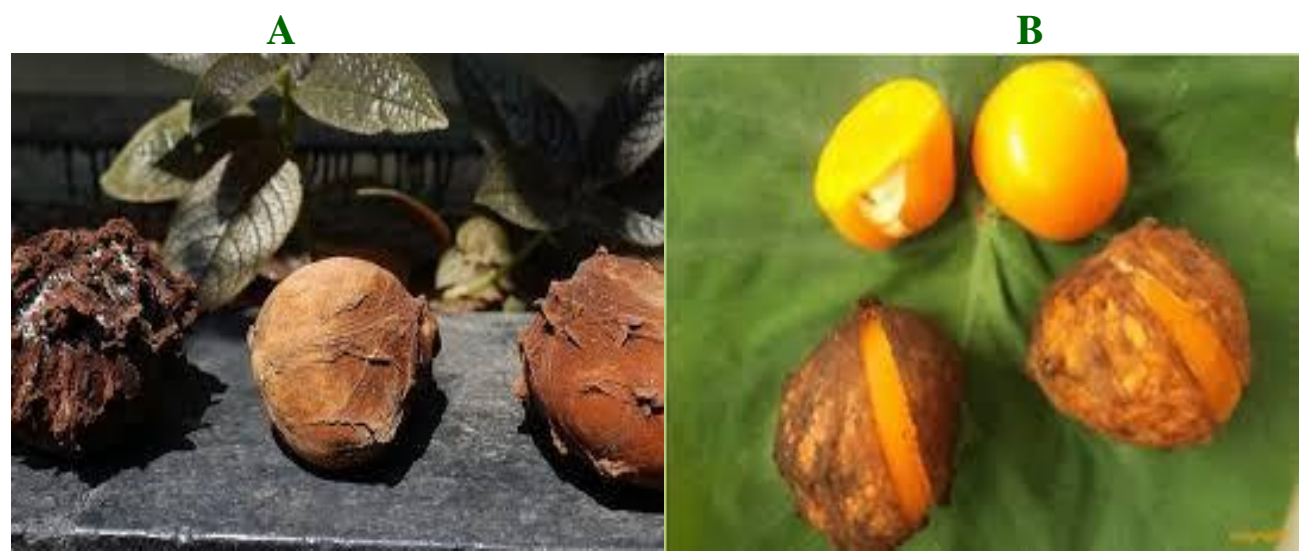




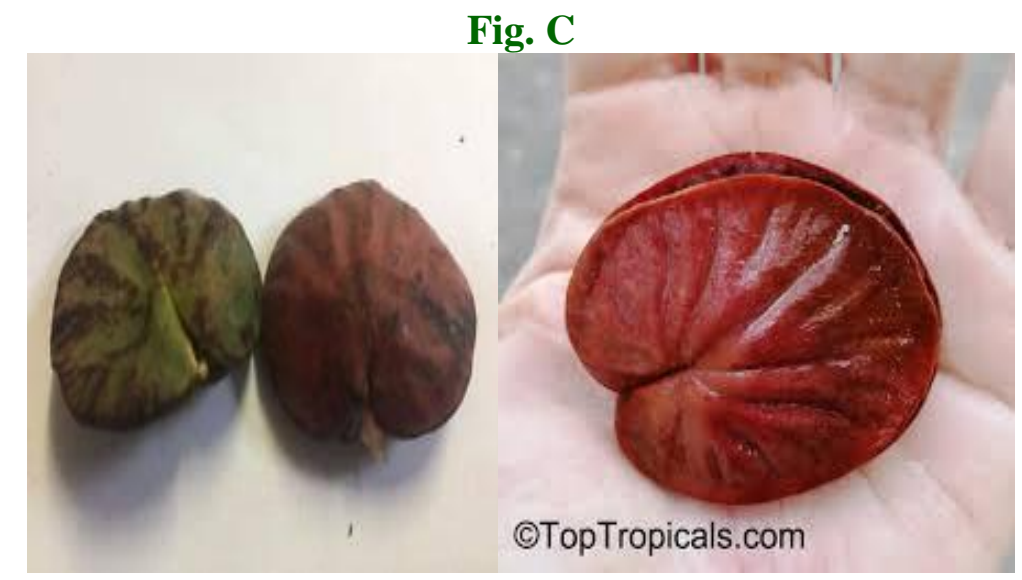

Ram et al., (1997) and Ahmed et al., (2010) suggested that the underlying mechanism of lipid lowering effect of $C$. lepidota could be by inhibition of lipid absorption due to the presence of saponins in Cola lepidota while Sharmila et al., (2007) suggested that the mechanism of lipid lowering effect of Cola lepidota could be as a result of inhibition of cholesterol esterase, activation of fatty acid synthase, acetyl-CoA carboxylase and production of triacylglycerol precursors such as acetyl-CoA and glycerol phosphate.

The fatty acid composition of the ethanolic seed extract revealed that linoleic acid methyl ester is the most prominent fatty acid compound contained in the seed extract and studies have shown that replacing either saturated fatty acid (SFA) or carbohydrate with linoleic acid reduces LDL-C and $\mathrm{TCH}$ to HDL-C ratio (Kris-Etherton and $\mathrm{Yu}, 1997$; Mensink et al., 2003) and higher intake of linoleic acid was not associated with inflammatory cytokines in humans (Harris et al., 2009). Therefore, the presence of linoleic acid in the seed extract could be contributory to the hypolipidemic effects as reported by Ekweogu et al., (2018).

It is very important to explore the plant world in order to naturally remedy certain disease conditions posing threat to humans like obesity, cancer, atherosclerosis, hypertension, myocardial infarction, diabetes mellitus,
AIDS, etc, since plants have been shown to possess a wide variety of natural products with diverse structural characteristics making many of them capable of treating diseases.

Cola lepidota seeds are recommended for further studies in order to reveal their potency in treating a targeted chronic disease conditions like hyperlipidaemia, diabetes, obesity or any other cardiovascular disease, considering the fact that they are good repository for several important phytochemicals.

\section{References}

Ahmed, O. M., Monain, A. A., Yazid, I. A. and Mahmod, A. M. (2010). Antihyperglycemic, antihyperlipidaemic and antioxidant effects and the probable mechanism of action of Ruta graveoleus infusion and Rutin in nicotinamidestreptozotocin induced diabetic rats. Diabetol. Croat. 39: 15 - 35.

Alvesalo, J., Vuorela, H., Tammela, P., Leinonen, M., Saikku, P. and Vuorela, P. (2006). Inhibitory effect of dietary phenolic compounds on Chlamydia pneumonia in cell cultures. Biochem. Pharmacol. 71: 735 - 741.

Biljana, B. P. (2012). Historical review of medicinal plants' usage. Pharmacogn. Rev. 6(11): 1 - 5 .

Calderone, V., Chericoni, S., Martinelli, C., Testai, L., Nardi, A. and Morelli, I. 
(2004). Vasorelaxing effects of flavonoids: investigation on the possible involvement of potassium channels. Naunyn-Schmiedebergs Arch. Pharmacol. 370: 290 - 298.

Cirico, T. L. and Omaye, S. T. (2006). Additive or synergetic effects of phenolic compounds on human low density lipoprotein oxidation. Food Chem. Toxicol. 44: 510-516.

Clardy, J. and Walsh, C. (2004). Lessons from natural molecules. Nature, 432: 829 837.

Cos, P., Arnold, J. V., Dirk, V. B. and Louis, M. (2006). Anti-infective potential of natural products: How to develop a stronger in vitro 'proof-of-concept'. Journal of Enthnopharmacology, 106: 290-302.

Duraipandiyan, V., Ayyanar, M. and Ignacimuthu, S. (2006). Antimicrobial activity of some ethnomedicinal plants used by Paliyar tribe from Tamil Nadu, India. BMC Complementary altern. Med. 6: 35-41.

Duthie, G. G., Duthie, S. J. and Kyle, J. A. (2000). Plant polyphenols in cancer and heart disease: implications as nutritional antioxidants. Nutri. Res. Rev. 13: 79-106.

Ekweogu, C. N., Nwankpa, P., Egwurugwu, J. N., Etteh, C. C., Ugwuezumba, P. C., Chukwuemeka, O. G. (2018). Effects of ethanol extract of Cola lepidota seed on lipid profile and haematological parameters of Albino wistar rats. Int. J. Curr. Microb. Appl. Sci. 7(3): 3178 3186.

Enechi, O. C. and Ozougwu, V. E. O. (2014). Effects of ethanol extract of Mucuna prueiena leaves on the lipid profile and serum electrolytes of rats. Journal of Pharmacy and Biological Sciences, 9(2): $18-23$.

Essien, E. E., Peter, N. S. and Akpan, S. M. (2015). Chemical Composition and Antioxidant Property of Two Species of Monkey Kola (Cola rostrata and Cola lepidota K. Schum) Extracts. Euro. J. Med. Plants, 7(1): 31-37.
Fabricant, D. S. and Farnsworth, N. R. (2001). "The value of plants used in traditional medicine for drug discovery". Environ. Health Perspect, 109(1): 69 - 75.

Fornica, J. V. and Regelson, W. (1995). Review of the biology of quercetin and related bioflavonoids. Food Chem. Toxicol. 33: 1061-1080.

Hagerman, A. E., Ken, M. R. and Robyn, E. R. (2001). Tannins as biological antioxidants. Basic Life Sciences, 66: 495-505.

Harris, W. S., Mozaffarian, D., Rimm, E., KrisEtherton, P. and Rudel, L. L. (2009). Omega-6 fatty acids and risk for cardiovascular disease: a science advisory from the American Heart Association Nutrition Sub-committee of the Council on Nutrition, Physical Activity, and Metabolism; Council on Cardiovascular Nursing; and council on Epidemiology and Prevention. Circulation, 119: 902 907.

Hubbard, G. P., Wolffram, S., Lovegrove, J. A. and Gibbins, J. M. (2004). Ingestion of quercetin inhibits platelet aggregation and essential components of the collagenstimulated platelet activation pathway in humans. J. Thromb. Haemost. 2: 21382145.

Jung, M., Park, M., Lee, H. C., Kang, Y. H., Kang, E. S. and Kim, S. K. (2006). Antidiabetic agents from medicinal plants. Curr. Med. Chem., 13: 1203-1208

Karamac, M. (2009). In vitro study on efficacy of tannin fractions of edible nuts as antioxidants. Euro. J. Lipid Sci. Technol. 111(11): 1063-1071.

Ken, M. R., Stephane, C., Helaine, M. A., Mark, M. and Ann, E. H. (2002). Antioxidant activity of tannins and tannin-protein complexes: assessment of in vitro and in vivo. Free Radicals in food, 14: 188-200.

Khalijah, A., Molid, R. M., Shiau-Chuen, C., Won, F. W., Mohammadjavad, P., Aditya, A., Hazrina, H., Chung, Y. L. and Soon, H. T. (2013). Antidiabetic and antioxidant properties of alkaloids from 
Catharanthus roseus (L.) G. Don. Molecules, 18 (8): 9770-9784.

Kim, W. C., Shahid, I. B., Nicholas, M. H., Khong, A., Der-Jiun, O., Maznah, A. and Ismail, A. (2014). Antioxidant activity of phenolics-saponins rich fraction prepared from defatted kenaf seed meal. LWTFood Sci. Technol. 56(1): 181-186.

Koleckar, V., Kubikova, K., Rehakova, Z., Kuca, K., Jun, D., Johodar, L. and Opletal, L. (2008). Condensed and hydrolysable tannins as antioxidants influencing the health. Mini Rev. Med. Chem. 8(5): 436-447.

Kris-Etherton, P. M. and Yu, S. (1997). Individual fatty acid effects on plasma lipids and lipoproteins: human studies. Am. J. Clin. Nutr. 65: 1628- 1644.

Mensink, R. P., Zock, P. L., Kester, A. D. and Katan, M. B. (2003). Effects and carbohydrates on the ratio of serum total to HDL cholesterol and on serum lipids and apolipoproteins: a meta-analysis of 60 controlled trials. Am. J. Clin. Nutr. 77: 1146 - 1155 .

Miyake, Y., Yamamoto, K., Tsujihara, N. and Osawa, T. (1998). Protective effects of lemon flavonoids on oxidative stress in diabetic rats. Lipids, 33: $689-695$.

Mladenka, P., Zatloukalova, L., Filipsky, T. and Hrdina, R. (2010). Cardiovascular effects of flavonoids are not caused only by direct antioxidant activity. Free Radiac. Biol. Med. 15: 963 - 975.

Muhammad, Z., Shakeel, A., Ryszard, A. and Vincenzo, D. (2013). Antioxidant activity of the extracts of some Cowpea (Vigna unguiculata (L) Walp.). Cultivars Common Consumed in Pakistan. Molecules, 18: 2005-2017.

Murray, C. J. T. and Lopez, A. D. (1996). The Global Burden of Disease: A Comprehensive Assessment of Mortality and Disability from Diseases, Injuries, and Risk factors in 1990 and Projected to 2020. Boston, Mass: Harvard School of Public Health.

Najla, G. S., Nazamid, S., Amin, I., Alfi, K., Fawzi, M. and Azizah, A. H. (2012).
Plants' metabolites as potential antiobesity agents. The scientific World Journal, 2012: 436039.

Ogbu, J. U., Essien, B. A. and Kadurumba, C. H. (2007). Nutritional value of wild Cola spp. (monkey kola) fruits of southern Nigeria. Nig. J. Hort. Sci.12: $113-117$.

Oghenerobo, V. I. and Falodun, A. (2013). Antioxidant activities of the leaf extract and fractions of Cola lepidota K. Schum (Sterculiaceae). Nig. J. Biotech. 25 (2013): 31-36.

Oktay, M. Gulcin, I. and Kufrevioglu, O. I. (2003). Determination of in vitro antioxidant activity of Fennel (Foeniculum vulgare) seed extracts. Lebensm. Wiss Technol. 36: 363-371.

Okudu, H. O., Ene-Obong, H. N. and Asumugha, V. U. (2015). The chemical and sensory properties of juice developed from two varieties of monkey kola (Cola parchycarpa, Cola lepidota). Afri. J. Food Sci. Technol. 6(5): 149-155.

Pamplona-Roger, G. D. (2008). Encyclopedia of foods and their healing power. In: Umeh, A. S., Nwadialu, M. A. (2010). Production and proximate analysis of jam (food spread) prepared from Cola parchycarpa. JHER, 13: 152-158.

Ram, A., Lauria, P., Gupta, R., Kumar, P. and Sharma, V. N. (1997). Hypocholesteromic effects of Terminalia arjuna tree bark. J. Ethnopharmacol. 55: $165-169$.

Rice-Evans, C., Miller, N. and Paganga, G. (1997). Antioxidant properties of phenolic compounds. Trends Plant Sci. 2: $152-159$.

Rump, A. F., Schussler, M., Ascar, D., Cordes, A., Ratke, R. and Theisohn, M. (1995). Effects of different inotropes with antioxidant properties on acute regional myocardial ischemia in isolated rabbit hearts. Gen. Pharmacol. 26: 603-611.

Ryszard, A. (2007). Tannins: the new natural antioxidants? Eur. J. Lipid Sci. Technol. 109(2007): 549-551.

Sachdeva, S., Sachdeva, T. R. and Sachdeva, R. (2013). Increasing fruit and vegetable 
consumption challenges and opportunities. Indian J. Community Med. 38: 192-197.

Sakihama, Y., Cohen, M. F., Grace, S. C. and Yamasaki, H. (2002). Plant phenolic antioxidant and prooxidant activities: phenolics-induced oxidative damage mediated by metals in plants. Toxicology, 177: 67-80.

Sharmila, B. G., Kumar, G. and Pandian, M. R. (2007). Cholesterol lowering activity of aqueous fruit extract of Trichosanthea dioica Roxb (L.) in normal and ST2 diabetic rats. J. Clin. Diagn. Res. 1: 561569.

Shiundu, K. M. (2002). Role of African leafy vegetables (ALVs) in alleviating food and nutrition insecurity in Africa. AJFNS, 2:96-97.

Sofowara, A. (1993). Medicinal plants and Traditional medicine in Africa. Spectrum Books Ltd, Ibadan, Nigeria. Pages, 289.

Stojanoski, N. (1999). Development of health culture in Veles and its region from the past to the end of the $20^{\text {th }}$ century. Veles: Society of science and art. 13-34.

Subarnas, A. and Wagner, H. (2000). Analgesic and anti-inflammatory activity of the proanthocyanidins Shellegueain A from Polypodium feei. Phytomedicine, 7: 401405.
Sumner, J. (2000). The National History of Medicinal Plants. Timber Press, 17. ISBN 0-88192-483-0.

Swain, T. (1968). Plants in the development of modern medicine. Harvard University Press. ISBN 0-674-67330-1.

Trease, G. E. and Evans, W. C. (1989). Pharmacognisy. 11th edn. Brailliar Tiridel Can. Macmillian publishers.

Valensi, P. E., Beher, A., De Champvallins, M. M., Attalah, M., Boulakia, F. C. and Attali, J. R. (1996). Effects of a purified micronized flanoid fraction on capillary filtration in diabetic patients. Dibet. Med. 13: 882-888.

Weber, J. M., Ruzindana-Umunyana, A., Imbeault, L. and Sircar, S. (2003). Inhibition of adenovirus infection and adenine by green tea catechins, Antivir. Res. 58: 167-173.

Widlansky, M. E., Duffy, S. J., Hamburg, N. M., Gokce, N., Warden, B. A. and Wiseman, S. (2005). Effects of black tea consumption on plasma catechins and markers of oxidative stress and inflammation in patients with coronary artery disease. Free Radic. Biol. Med. 38: 499-506.

Zschocke, S., Rabe, T., Taylor, J. L., Jager, A. K. and Van, S. J. (2000). Plant part substitution-a way to conserve endangered medicinal plants? J. Ethnopharmacol. 71(1-2): 281-292.

\section{How to cite this article:}

Chukwuemeka, O.G., P.N. Okafor, P. Nwankpa, C.C. Etteh, C.N. Ekweogu, P.C. Ugwuezumba, F.C. Emengaha, J.N. Egwurugwu and Izunwanne, D.I. 2018. Qualitative Phytochemical Screening and GCMS-Derived Fatty Acid Composition of Ethanolic Seed Extract of Cola lepidota K. Schum. Int.J.Curr.Microbiol.App.Sci. 7(12): 12-24.

doi: https://doi.org/10.20546/ijcmas.2018.712.002 